\title{
3 Research Suare \\ Contextualization of the Shane Theory and the Entrepreneurial Learning Model at University: A Narrative Method
}

\section{R. Tri Priyono Budi Santoso}

Universitas Dhyana Pura Bali

\section{Wayan Ruspendi}

Universitas Dhyana Pura Bali

Sony Heru Priyanto ( $\nabla$ sonecid@yahoo.com )

Universitas Podomoro https://orcid.org/0000-0002-5016-1748

Donald Samuel Slamet Santoso

Universitas President

\section{Research}

Keywords: entrepreneurial learning model, start-up, Shane Theory, narrative method

Posted Date: November 13th, 2020

DOI: https://doi.org/10.21203/rs.3.rs-104538/v1

License: (a) (i) This work is licensed under a Creative Commons Attribution 4.0 International License.

Read Full License

Version of Record: A version of this preprint was published at Journal of Innovation and Entrepreneurship on July 8th, 2021. See the published version at https://doi.org/10.1186/s13731-021-00162-8. 


\section{Abstract}

The novelty of this research is in applying the construction of the Shane Theory and the ELM Theory in applying Entrepreneurship Education at higher education institutions. This study used action research by utilizing a narrative method. The business field which matched with the academic discipline as well as hobby was more successful than that which was different had a prospect as a start-up. Leadership, entrepreneurship and managerial ability were determining factors in the success of a start-up company. It can delve more into the entrepreneurship process of start-ups to recognize opportunities to create ideas, start businesses, and develop businesses.

\section{Introduction}

This research was conducted due to the fact that business and management education has too many theories and quantitative analyses but does not emphasize as much in qualitative factors; is too focused on instruments, concepts, and models; is too bureaucratic in applying management; and does not apply enough entrepreneurial activities. Professors and educators often work in a non-real condition rather than dealing with important issues (Van Vuuren \& Nieman, 1999), so that a transformation is needed to the direction of the entrepreneurial learning model.

One of the causes of failure in achieving economic growth and economic development of a country is because there is no entrepreneurship, whether at the individual level, organizational level, or societal level. Previous researchers have stated that entrepreneurship plays a great role in economy building (Kirzner, 1999), and entrepreneurship is a vital component of productivity and growth (Baumol, 1993). Szirmai, Naudé, and Goedhuys (2011) stated that various literature has neglected the potential role of entrepreneurs as innovators in developing countries. Joseph Schumpeter showed that one century ago entrepreneurs were often innovators, who brought goods and new technology to the market; opened new markets, processes, and ideas; and commercialized new knowledge. However, it was often misinformed that the innovations done by entrepreneurs were not important for the growth of developing countries with low revenue compared with more advanced countries. Unfortunately, many citizens prefer to be employees rather than entrepreneurs.

Related with this, to improve the number of entrepreneurs, education and training are needed. Unfortunately, there is not a standard format and structure for entrepreneurship education. Moreover, higher education institutions do not have any set standards in developing entrepreneurship education. For non-formal and informal education, even though there is entrepreneurship education, the form is still in skilled education, whereas entrepreneurship does not have any skills incorporated in it.

Based on the explanation above, it shows that entrepreneurship education is very important, but related with education and its learning it is still not clear. From here, theoretical testing about this is very open, keeping in mind that the entrepreneurship education model and its relationship with entrepreneurial performance is still ambiguous and various and usually related with the distinctiveness of each country 
(Weaver, Dickson, \& Solomon, 2006). Furthermore, the current curriculum is not yet suitable to become Entrepreneurship Education curriculum, such as what was stated by Kourilsky (1995) in that "Most of today's school curricula do not even address Entrepreneurship Education for the initiator level of the pyramid" and to addressed to cognitive factor (Johannisson, 2018).

As of now, students still enjoy being jobseekers rather than entrepreneurs. To deal with this problem, Universitas Dhyana Pura Bali (Undhira) has changed the curriculum by including an Entrepreneurship course. There is entrepreneurship practice, but usually it stops after the grades are released, whereas actually there is great business potential that students can do when they are still students, especially for hotel, tour, restaurant, and café businesses, as well as provide and manage new tourism locations in Bali. After a learning evaluation is done, it seems there are still mismatches in applying the entrepreneurship learning method, which until is not much different with the learning methods of other courses, which emphasize more on face-to-face structured activities in the classroom.

Related with this, in 2019, Universitas Dhyana Pura conducted Entrepreneurship Education for its students through an Entrepreneurship Development Program from the Ministry of Research and Technology of Higher Education (Ristek Dikti). Undhira designed and built an Experiential Learning Model (ELM) in the form of a business project for students by taking advantage of the available technology (technopreneurship) at higher education institutions. In their learning, students must make business projects directly, with assistance from company mentors who have already been a success, but first they must do internships at the mentors' workplaces. The work solution framework uses a concept from Priyanto (2012), which consists of changes to the mindset, entrepreneurial skills, business skills, and ready skills, and the Shane Theory (2003), which consists of entrepreneurial motivation, cognitive factors, job opportunities, and a supporting business environment. From this program, research is conducted about the dynamics of Entrepreneurship Education at higher education institutions and their effects on the growth of students' entrepreneurship spirit.

\section{Literature Review}

\subsection{Entrepreneurship Theory in a Time Dimension}

At the beginning of the 20th century, entrepreneurship was a hot topic because of its important role in building economies. Schumpeter (1934) stated that if a country has many entrepreneurs, then its economic growth will be high and produce high economic development. If a country strives to become advanced, there should be a large number of entrepreneurs. "Entrepreneurship is a driving force behind economic growth." Kirzner stated that entrepreneurship is an important part of development (Kirzner, 1999).

The rationalization is that if someone has an entrepreneurship, he/she will possess high motivation/leadership (need of achievement), be brave to try things (risk taker), as well as be innovative and independent. With these characteristics, with some opportunities and changes, the individual will be 
able to change, produce something new, have new relations, and accumulate capital, whether in the form of company improvements (upgrading) or establishing a new company. With this effort, it will drive raw materials to change into something that is more valuable, so that eventually consumers will want to buy it. In this process, there will be an exchange of goods and services, whether in the form of natural resources, money, social resources, opportunities, or human resources. In economics knowledge, if this occurs, it means there is economic growth; and if there is economic growth, it means there is development.

One of the reasons for failure in achieving economic growth and economic development in a country is because there is no entrepreneurship, whether at the individual level, organizational level, or societal level. Previous researchers stated that entrepreneurship plays a great role in economic development (Kirzner, 2015), is a vital component of productivity and growth (Baumol, 2003), plays a role in improving investments and doing new business creation (Gartner, Carter, \& Reynolds, 2010), results in job training (Kristof-Brown, Zimmerman, \& Johnson, 2005) and home-base businesses (Hull, 2010), improves employment growth (Link \& Scott, 2012), creates national identity and leadership (Reicher, Haslam, \& Platow, 2018), and together with management capacity greatly contributes to the firm's success (Priyanto \& Sandjojo, 2005). Schumpeter (1934) even stated that entrepreneurship is the driving force behind economic growth, formulating a new economic combination by (1) developing new products; (2) developing new sources of materials; (3) accumulating capital resources; (4) introducing new products and new production functions; and (5) reorganizing or developing a new industry.

Entrepreneurship also plays a significant role in developing small and medium enterprises. Previous research showed that low performance in small industries is due to several factors, including poor entrepreneurial characteristics. Entrepreneurship is the driver which plays a role in developing industries (Ács \& Naudé, 2013; lakovleva, Kolvereid, \& Stephan, 2011).

Entrepreneurship also has a direct influence on business performance. Baum, Locke, and Smith (2001) stated that a person's characteristics (which can be measured from one's rigidity in facing problems, and having a proactive attitude and enjoyment in doing one's job), general competence (which can be measured from one's organizational expertise and ability to see opportunities), unique competence which is possessed like industry expertise and engineering expertise, as well as motivation (which can be measured from the vision, growth goals, and self-efficacy), have a positive influence towards the company growth. This is similar with Baum et al. (2001) as well as Lee and Tsang (2001), who concluded that entrepreneurship elements like an internal locus of control, a need for achievement, education experience, and self-reliance influence the company growth.

If observing and paying attention to the meaning of development or the definition of entrepreneurship, it seems that entrepreneurship is not just education in running a company. As stated by Blaise (2011), entrepreneurship is the personal development of an individual to be able to have creativity, be innovative, be brave to try something new, be independent, and have a desire to advance, which will enable an individual to cooperate with other parties to develop the business. 
Stevenson differentiated between entrepreneurship, a business, and a manager. These three terms are different but can be strongly related in running a company (Stevenson \& Jarillo, 1990). According to Priyanto (2012), the success of a business can be reached if the entrepreneur has an entrepreneurial spirit and management capacity together.

\subsection{Entrepreneurship Education}

From the various definitions that have been proposed, there is some expertise which must be learned in Entrepreneurship Education, such as according to Morris and Jones (1989, p. 74), who stated, "Identify and evaluate an opportunity. Define a business concept. Identify the needed resources. Acquire the necessary resources. Implement, operate, and harvest the venture."

Meanwhile, there are several things which must be possessed by an entrepreneur, so that they should be included in the Entrepreneurship Education curriculum, including leadership, communication (oral/written), human relations/ hiring, management, deal-making/ negotiating, logical/analytical thinking, decision-making and goal-setting, and business plan preparation (D. L. Bolton \& Lane, 2012; P. Bolton, Brunnermeier, \& Veldkamp, 2010; Hood \& Young, 1993; Siedel, 2014).

In Entrepreneurship Education, many models and concepts have been developed. In general, an Entrepreneurship Education model contains various goals like changing one's viewpoint or mindset, changing the entrepreneurship expertise, being able to make a business plan, and having the ability to communicate. The main purpose of all of this is to be able to prepare students to be able to capture opportunities and be able to implement these opportunities to become more valuable business activities.

Entrepreneurship Education has in the last decade, grown in stature and numbers as a popular and innovative part of the business curriculum. Entrepreneurship Education seems to be one of the most important fields of development for the fact that entrepreneurs are seen as the people who are driving the economies of countries, and entrepreneurship is seen as the engine of the growing economy in the millennium we are in (Noyes \& Deligiannidis, 2013; Thom, 2017; Van Vuuren \& Nieman, 1999; Welsch, 1993)

Business and Management Education is too full of theories and quantitative analyses, and does not emphasize qualitative factors; is too focused on instruments, concepts, and models; is too bureaucratic in applying management; and does not apply enough entrepreneurial activities. Professors and students often work in unreal conditions compared to dealing with important problems (Pretorius, Nieman, \& Van Vuuren, 2005). Education which leads to students' self-mastery in preparing them to enter the real world can improve their entrepreneurial spirit.

In detail, Entrepreneurship Education consists of a change in mindset. This is a basic and primary activity in Entrepreneurship Education. Changing one's mindset is the key to success in forming strong entrepreneurial characteristics. Entrepreneurial skills include attitudes, behaviors, and unique processes that are different from workers and managers. Ready skills are expertise and knowledge that are ready to 
be used like IT expertise. Business functions are the ability to run a business like planning until controlling.

\subsection{Applying the Shane Theory in Entrepreneurship Education in Higher Education Institutions}

The primary factor which influences entrepreneurship is one's individual environment. In this individual environment, the role of an individual's personality greatly determines one's entrepreneurship ability. In this factor, entrepreneurial motivation is an aspect which has a significant effect on many things. According to Shane et al. (2003), this entrepreneurial motivation consists of the need of achievement, a locus of control, a vision, a desire for independence, a passion, a drive, goal setting, and self-efficacy. These motivational factors are combined with cognitive factors like knowledge to influence a person's entrepreneurship ability. Entrepreneurial opportunities and environmental conditions along with entrepreneurship motivation and cognitive factors will also become the backbone of entrepreneurship.

Motivation greatly influences entrepreneurship. Entrepreneurship starts from recognizing entrepreneurial opportunities and is then followed by developing ideas in how to reach these opportunities, evaluate their suitability, develop products and services to fulfill consumer needs, intertwine financial and human resources, design the organization, and hunt for consumers. Shane et al. (2003) suggested that some or all of this motivation will influence the transition of the individual entrepreneurship formation process from one stage to the next one. What is certain is that this motivational aspect is one of the ways to shape entrepreneurship. Another important variable is the cognitive factor, which includes the vision, knowledge, skills, and abilities. All of these actions are a combination of interaction results, the integration of motivation and cognition (Locke, 2000).

The importance of the cognition aspect being in the form of knowledge is that it makes the vision capable to influence someone's entrepreneurial ability. An individual who understands the importance and role of a vision will strive to make and record one's life vision. When the person makes the vision, it will result in an aware desire that the person will reach the vision. Second, knowledge becomes an important resource for entrepreneurship. A person who knows something will be better able to piece together a structure, a system, and new ideas than someone who does not have much knowledge. A person who is full of knowledge will easily look for another path when the person experiences a particular difficulty. Or the individual will be able to see opportunities or have new ideas with the knowledge one possesses. Third, a person who has expertise will also be able to create ideas and innovations that are based on the skills that one has. With the skills that one possesses, a person will be better able to create to add, perfect, and even replace the ideas. A person who has expertise in making organic fertilizer will find it easier to adjust oneself if there is a change in the availability of raw materials compared with someone who is not an expert. This signifies that it is important for us to become experts in the fields that we undertake, so that it allows us to be more creative and innovative than before.

\section{Research Methodology}


This research applied the construction results of the Shane Theory and ELM in conducting Entrepreneurship Education at higher education institutions, in order to create start-ups, with a mixed framework (a blended entrepreneurial model framework) as Table 1:

Table 1

Framework of research

\begin{tabular}{|c|c|c|c|}
\hline \multirow{2}{*}{$\begin{array}{l}\text { Shane Theory } \\
\text { Stages }\end{array}$} & \multicolumn{3}{|c|}{ Entrepreneurial Learning Model (ELM) } \\
\hline & Training \& Education & Experience & Mentoring \\
\hline \multirow[t]{2}{*}{$\begin{array}{l}\text { Entrepreneurial } \\
\text { motivation }\end{array}$} & $\begin{array}{l}\text { Self-introduction, improving } \\
\text { business motivation }\end{array}$ & \multirow{2}{*}{$\begin{array}{l}\text { Actualizing one's } \\
\text { desires, test stage, } \\
\text { independence, } \\
\text { creativity, innovation }\end{array}$} & \multirow{2}{*}{$\begin{array}{l}\text { Sublimate the ways to } \\
\text { reach success through } \\
\text { what has been done by } \\
\text { the mentor }\end{array}$} \\
\hline & $\begin{array}{l}\text { Instilling a life vision \& } \\
\text { leadership effort }\end{array}$ & & \\
\hline $\begin{array}{l}\text { Cognitive } \\
\text { factor }\end{array}$ & $\begin{array}{l}\text { Understand about the life vision } \\
\text { and company, the kind of } \\
\text { company, and expertise in } \\
\text { running the company }\end{array}$ & $\begin{array}{l}\text { Company visits, } \\
\text { doing experiments }\end{array}$ & $\begin{array}{l}\text { Understanding what } \\
\text { has been done by the } \\
\text { mentor }\end{array}$ \\
\hline $\begin{array}{l}\text { Entrepreneurial } \\
\text { opportunity }\end{array}$ & $\begin{array}{l}\text { Understanding about business } \\
\text { opportunities }\end{array}$ & $\begin{array}{l}\text { Determine } \\
\text { prospective } \\
\text { business plans }\end{array}$ & $\begin{array}{l}\text { Learn about the } \\
\text { mentor's business to } \\
\text { determine the } \\
\text { company's plan }\end{array}$ \\
\hline $\begin{array}{l}\text { Environmental } \\
\text { condition }\end{array}$ & $\begin{array}{l}\text { Understand about the macro } \\
\text { and micro environments }\end{array}$ & $\begin{array}{l}\text { Provide a business } \\
\text { environment which } \\
\text { is conducive for the } \\
\text { business }\end{array}$ & $\begin{array}{l}\text { Provide a mentor } \\
\text { business environment } \\
\text { for tenants }\end{array}$ \\
\hline $\begin{array}{l}\text { Opportunity } \\
\text { recognition }\end{array}$ & $\begin{array}{l}\text { Recognize business } \\
\text { opportunities }\end{array}$ & $\begin{array}{l}\text { Arrange business } \\
\text { alternatives }\end{array}$ & $\begin{array}{l}\text { Describe the factors of } \\
\text { business success that } \\
\text { are done by the mentor }\end{array}$ \\
\hline $\begin{array}{l}\text { Idea } \\
\text { development }\end{array}$ & Understand the business plan & $\begin{array}{l}\text { Arrange business } \\
\text { plans }\end{array}$ & $\begin{array}{l}\text { Learn from the mentor's } \\
\text { business plans }\end{array}$ \\
\hline Execution & $\begin{array}{l}\text { Understand about assembling } \\
\text { resources, organizational } \\
\text { design, market making, and } \\
\text { product development }\end{array}$ & Run a business & $\begin{array}{l}\text { Receive assistance } \\
\text { from the mentor }\end{array}$ \\
\hline
\end{tabular}


Table 2

Description of Tenant

\begin{tabular}{|c|c|c|c|c|c|c|}
\hline No. & Tenant & Major Study & Product Item & $\begin{array}{l}\text { Product } \\
\text { Output }\end{array}$ & Impact & Note \\
\hline 1 & Group & Physiotherapy & $\begin{array}{l}\text { Mobile-Based } \\
\text { Physiotherapy } \\
\text { Home Care } \\
\text { Application }\end{array}$ & Prototype & $\begin{array}{l}\text { Improving } \\
\text { skill }\end{array}$ & $\begin{array}{l}\text { The mobile } \\
\text { based } \\
\text { business } \\
\text { isn't ready } \\
\text { yet }\end{array}$ \\
\hline 2 & Group & Physiotherapy & $\begin{array}{l}\text { Natural, Healthy, } \\
\text { and Clean } \\
\text { Cosmetic } \\
\text { Innovation } \\
\text { Jackfruit Leaf } \\
\text { Body Scrub }\end{array}$ & Model & $\begin{array}{l}\text { Improving } \\
\text { skill }\end{array}$ & $\begin{array}{l}\text { The } \\
\text { product } \\
\text { has not } \\
\text { been } \\
\text { marketed }\end{array}$ \\
\hline 3 & Group & Physiotherapy & $\begin{array}{l}\text { “Mask Damba” } \\
\text { Neem Leaf Mask }\end{array}$ & Model & $\begin{array}{l}\text { Improving } \\
\text { skill }\end{array}$ & $\begin{array}{l}\text { The } \\
\text { product } \\
\text { has not } \\
\text { been } \\
\text { marketed }\end{array}$ \\
\hline 4 & Group & Physiotherapy & Mayusi Cloth & Model & $\begin{array}{l}\text { Improving } \\
\text { skill }\end{array}$ & $\begin{array}{l}\text { The } \\
\text { product } \\
\text { has not } \\
\text { been } \\
\text { marketed }\end{array}$ \\
\hline 5 & Group. & Physiotherapy & $\begin{array}{l}\text { "Physio Care" } \\
\text { Aromatherapy } \\
\text { Rubbing Oil } \\
\text { Business Plan }\end{array}$ & Product & $\begin{array}{l}\text { Initial } \\
\text { Product }\end{array}$ & $\begin{array}{l}\text { Start Up; } \\
\text { Difficult to } \\
\text { create new } \\
\text { market }\end{array}$ \\
\hline 6 & Group & Physiotherapy & $\begin{array}{l}\text { "AnRe" Ankle } \\
\text { Rehabilitation } \\
\text { Shoes }\end{array}$ & Product & $\begin{array}{l}\text { Initial } \\
\text { Product }\end{array}$ & $\begin{array}{l}\text { Start Up; } \\
\text { Developing } \\
\text { The } \\
\text { Market }\end{array}$ \\
\hline 7 & Individual & Psychology & $\begin{array}{l}\text { Banana Pizzat } \\
\text { (Pizzang) }\end{array}$ & Business & $\begin{array}{l}\text { Profit; } \\
\text { Market \& } \\
\text { Product } \\
\text { Development }\end{array}$ & $\begin{array}{l}\text { Start Up; } \\
\text { He has } \\
\text { been } \\
\text { serving } \\
\text { consumers } \\
\text { through } \\
\text { online } \\
\text { media }\end{array}$ \\
\hline 8 & Individual & Management & $\begin{array}{l}\text { Technology Based } \\
\text { Duck Egg Hatching }\end{array}$ & Business & $\begin{array}{l}\text { Profit; } \\
\text { Market \& } \\
\text { Technology } \\
\text { Development }\end{array}$ & $\begin{array}{l}\text { Start Up; } \\
\text { He is trying } \\
\text { to meet the } \\
\text { high } \\
\text { demand }\end{array}$ \\
\hline
\end{tabular}

This research used the narrative-action research approach by Chase (2005), which resembles the definition of a narrative analysis by Polkinghorne $(1995,2007)$, who suggested that a researcher should 
use a paradigmatic reason for a narrative study, such as how students in a campus entrepreneurship development program are given education and training to attempt to make a business directly and receive mentoring in a social situation within an entrepreneurship interactive appearance, and how the researcher can build interpretations from the entrepreneurship social situation.

This research also used a biography study, where the researcher wrote and recorded about individual life experiences. An autobiography is written and recorded by an individual as a test subject about the life history and experiences of someone (De Fina \& Georgakopoulou, 2019; Floyd, 2012), who is related with the entrepreneurship.

The stages in carrying out this activity can be explained as follows:

1. Determine the best research problems or questions which are appropriate for narrative research, in order that it can capture the story details or life experiences towards a person's life or several individuals' lives.

2. Choose 8 individuals who have entrepreneurship life experiences or stories to be told, and conduct an entrepreneurship development program with them to collect their stories through a diverse information method.

3. Collect stories about the entrepreneurship context.

4. Analyze the participants' stories and then retell their stories in a work framework which makes sense. Retelling is an organizational process of sharing a story again in several general types of a work framework. This work framework involves collecting information, analyzing information for the key elements of a story (such as the time, place, flow, and scene), and rewriting a story to place themselves in a chronological series of events.

5. Collaborate with the participants through their active involvement in research. Keep in mind that researchers collect the stories, then they negotiate the relationships, use smooth transitions, and provide a useful method for the participants.

The research activities began by first applying ELM, starting from the program socialization stage, an entrepreneurship seminar that ended with an entrepreneurship potential test, a selection of business ideas, a proposal selection process, grant provisions, business implementation, mentoring by an entrepreneur, an internship, monev, a business exhibition, and participation in an entrepreneur community. This model was applied for all 10 participants. In the seminar stage, 100 individuals were involved. From this total, 16 business proposals were selected that had to have their business ideas presented. From this total, 10 students were chosen and given an entrepreneurship stimulus grant and business mentoring. There were 8 batik businesses that were successful in running their operations, whether individually or in groups, where two of the businesses were able to significantly show their performance.

Data was retrieved by using direct observations of their activities, starting from an entrepreneurship potential test until running their businesses on a daily basis. When they were doing their businesses, there was a mentor who also collected data. The data was gathered through a data processing process like 
reduction, grouping, and arranging the themes and patterns. The analysis method used a descriptive qualitative analysis in the form of a narrative method.

\section{Results And Discussion}

\subsection{Research Results}

This research used a descriptive qualitative approach by providing an Entrepreneurship Education program. The results of the research which are related with the tenant company profiles can be explained narratively related with the participants' exposure to the entrepreneurship development program as follows:

\section{Mobile-Based Physiotherapy Home Care Application}

The individuals who developed a mobile-based physiotherapy home care application are students from Universitas Dhyana Pura, including I Wayan Agus Surasa, Kadek Adi Kusumadana, and Ni Luh Putu Munia Anggreni. These students were advised by a lecturer named Ir. I Gede Arya Sena M. Kes. The development of this application was based on improving disruptions in society's health, especially related to bone issues or strokes. The purpose of this business is to provide a quick service to society by taking advantage of technological developments.

Health is an important issue that is yearned for by all people. However, various people experience poor health, as a result of an unhealthy lifestyle and overdoing physical activities. Then new problems arise in society like distance limitations, time, comfort level, as well as slow service. By having a mobile-based physiotherapy home care application, it is expected to be able to help the general public, in order to facilitate them in making their time and distance more efficient, as well as make the patients more comfortable, because they will be in an environment they recognize. The home care application making process consists of identifying the problem, gathering data, analyzing the needs, designing an application, implementing it, and evaluating it. This business has a great opportunity to be developed in the market, because it has several advantages that pay attention to the market target and business planning in running the mobile-based business.

This home care application is still a prototype; the business model has not been created yet. It seems the team has an obstacle that cannot be overcome to develop it, which has made the business stagnant.

\section{Natural, Healthy, and Clean Cosmetic Innovation Jackfruit Leaf Body Scrub}

This business was developed by students from Universitas Dhyana Pura named Ni Putu Ari Meiyani Suriatha Putri, Luh Putu Anggun Ema Pratiwi, and Putu Edo Prananta. A lifestyle is something which must be fulfilled by all individuals today. By having an appearance that is physically appealing, it can make individuals have more confidence in socializing. Having an interesting appearance while keeping the skin clean is important for women or men to have more confidence in doing their daily activities. One of the skin care products that is usually used to clean dirt from the skin is a body scrub. They did a 
creative innovation by utilizing dried jackfruit leaves with a mixture of dried jasmine flowers to make the aroma more fragrant and rose water as well as coconut oil as a dissolvent, so that it produced the UNANG body scrub product.

The UNANG body scrub product is a business innovation which is made with natural ingredients, so that it is appropriate for various kinds of skin and supported with a modern appearance. The product made from this business is not a new product being marketed, but the uniqueness of this product is that they are certain that this business has a great opportunity to be developed in the market.

In developing the UNANG body scrub business, there are factors which must be given attention, in order to expand this business, such as by choosing the right market target, having an appropriate marketing strategy, and determining a price which is affordable by all societal levels. If all of these factors have been fulfilled and are well planned, then the product that they are offering, the UNANG body scrub, will be very capable to compete in the market. Therefore, a business plan needs to be made as a reference in running the UNANG body scrub business.

This business has already produced a product which is complete with a composition sticker, but it has not developed rapidly because it has not been marketed on a massive scale and the product has not had laboratory tests to find out its benefits and side effects.

\section{3. "Mask Damba" Neem Leaf Mask}

This business was developed by students named Ni Luh Putu Munia Anggreni, Kadek Adi Kusumadana, and I Wayan Agus Surasa. These four students were guided by Ir. I Gede Arya Sena M. Kes. This idea arose in response to a problem that is experienced by society, and especially for teenagers. Looking interesting while protecting the skin, so that it seems clean and free of acne can help make someone more self-confident. Keeping one's face clean and interesting is very costly. Using a traditional mask can be one alternative to take care of one's face. Therefore, they tried to make a neem leaf mask, which is expected to be used to medicate and eliminate acne. They are certain this business can be developed in the market because of several unique product aspects. One of them is that it has natural basic ingredients, so that it will not have any side effects if used for a long-term period. In making this face product, several factors need to be given attention, such as in choosing the target market, deciding the market strategy, and determining the product price. Besides that, the sustainability of the business must also be considered, in order that this facial product can last for a long time in the market by giving new innovations for this product.

\section{4. "Physio Care" Aromatherapy Rubbing Oil Business Plan}

This business was developed by Ni Kadek Virnanda Candra Dewi, Ni Putu Suryaningsih Dewi, and I Made Rai Putra Adnyana. This idea surfaced to meet society's needs for aromatherapy oil. There is a great need for rubbing oil, but the pungent aroma of the oil and the old fashioned bottle make the image of rubbing oil unappealing for teenagers. They made a creative business innovation with a combination of fragrant 
essential oils and a mixture of rubbing oils like gandapura oil, clove oil, eucalyptus oil, and olive oil to become a fragrant rubbing oil. Besides that, with an innovation of a roll-on bottle, it will beautify one's appearance from the rubbing oil, so that one's appearance will look more interesting and match with today's developments. This is not a new business, but with the unique product that they are offering, they are certain that this business has a great opportunity to develop well in the market.

Many factors need to be considered to advance the Physio Care aromatherapy rubbing oil business. The most significant factor that needs to be considered to expand this company is by choosing appropriate marketing targets, having good marketing strategies, and setting affordable prices for society.

In addition, this business has not developed much since it is still in the laboratory scale and has not been marketed. It seems there are obstacles in the team with a lack of enthusiasm to develop the business to become a success. They are still limited in the production area. They are able to produce but unable to create a new market and value from the product.

\section{5. "AnRe" Ankle Rehabilitation Shoes}

This business was derived from the idea of Universitas Dhyana Pura students, including Ni Made Krisna Danayanti, Luh Made Sonia Indriany Savitri, and Ni Putu Ari Meiyani Suriatha Putri. This concept is a solution for sufferers of leg injuries. Ankle injuries are a problem that is often experienced by athletes or common people while exercising. The ankles must be protected to avoid the possibility of an injury. If an injury occurs, then the injured part should be given immediate treatment on the ankle joints. Making an innovative health equipment business like "AnRe Shoes" will facilitate someone to treat an injury without using a lot of equipment.

"AnRe Shoes" are very easy to use and simple to bring anywhere. Besides that, "AnRe Shoes" also have a fashionable design and are light to use, so that the users will still feel comfortable to wear these shoes.

This is not a new business, but with the uniqueness of the "AnRe Shoes" product, they are certain that this business has great potential to develop well in the market. Some of the factors which need to be given attention to develop this business include choosing the right market target, having good marketing strategies, and setting a price that is affordable for all levels of society, so that the "AnRe Shoes" product can compete in the market. If these factors are arranged well, then it will become a business with good development. Consequently, a business plan needs to be made as a reference in running this health equipment business.

While this business has been in operation, it has produced 5 pairs of shoes with 3 already sold and 2 as testimonies (were given for free), and there are still 3 more pairs in the making process, of which 1 pair will be displayed in a fitness center (gym). The obstacle is to find a shoemaker who can work together. Therefore, in the future, they will coordinate with the Amaranee Foundation to market the product and make a social media account to be more well-known.

\section{Banana Pizzat (Pizzang)}


Pizzang is a healthy snack with natural ingredients from a banana. To make the taste more enjoyable and appealing for teenagers, they added 8 flavor variants and 8 toppings that are popular with youths. The product will be sold in coordination with Ojek Online (Ojol), in order that it reaches a wider market. It has a mini outlet that is located on JI. Diponegoro No. 704 and operates from 12:00 PM to 9:00 PM.

Pizzang was established on 25 February 2018 with a focus as a company that provides a snack made from natural ingredients from bananas and is packaged with a modern concept that is different from its competitor, which is Pisang Nugget, but it is packaged differently. This can be seen from the shape which resembles a pizza and has unique packaging. The package uses a pizza box, in order that it really resembles an ordinary pizza. In addition, Pizzang creates its own spices that are different from its competitor. They do this because the buyer target is millennial kids, especially females between 12 and 30 years old. In today's era where people like to take pictures of their food before eating it, they see this as an opportunity to enter the millennial market by making Instagramable packaging by using a pizza carton box and in a pizza shape that is different from their competitor. This business is fully managed by Januarta.

The uniqueness of this product from its competitor is that it is the first banana nugget innovation in the form of a pizza, the packaging is very different from Pisang Nugget by using a pizza box, and it still has a banana texture, so that brings out the banana taste.

The Pizzang product has a price range of Rp 24,000 - Rp 40,000 and the additional toppings have a price range of $R p 5,000$ - Rp 6,000. This business has successfully added a new menu variant (drink) to develop the company. It is ready to open a new branch. The constraints that are faced are it is difficult to find workers to look after the food stand, and there is a lack of freezers. Freezers are very useful for keeping more of the Pizzang stock and to make ice for their drinks. In the future, they would like to separate their net profit to develop a new menu item. They have already saved enough to make a few new menu items to be tested and add to Pizzang, and at the end of 2020 they want to make a wider franchise in Bali.

For the business promotion strategies, they use a photo sharing service, like Instagram and Facebook, as well as join the applications Ojek Online (Ojol) Gojek and Grab, in order to expand their market reach. They have made a Line Official account and WhatsApp for Business, in order that the customers can place orders or ask about the product availability. Another thing that can be done with the two applications is that they can broadcast to the customers, so that they will all know if there is an interesting promotion at the same time.

In general, they target females between 12 and 30 years old, or what can be called the millennial group. They also target males with the branding that the product is a good choice to be given to a loved one. With various considerations, they estimated that on a daily basis they can sell 10 pans, where each pan costs $\mathrm{Rp} 26,000$. So, in one day they can receive a profit of $\mathrm{Rp} 260,000$ or an equivalent of $\mathrm{Rp} 6,760,000$

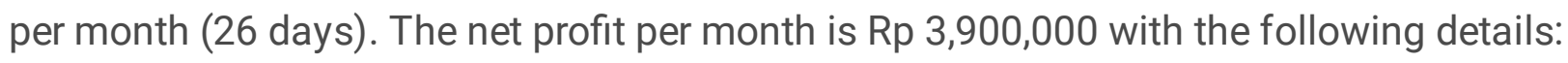


1. The production cost of one tray is $\operatorname{Rp} 13,000$.

2. If the daily target produces 10 trays, then it will become Rp 130,000.

3. In a month, they can obtain a net profit of Rp 3,900,000.

The development plan of this business does not only depend on one outlet. In the future, they want to open a partnership or franchise. They also want to open several mini stands in front of an Indomaret or Alfamart. In two years, they want to target whether they can open branches outside of Bali, such as outlets in Yogyakarta and Malang. Besides that, they plan to add fresh fruit juice drinks and Thai Tea drinks. Besides that, they want to add Milo as a menu item. Adding various menu and drink varieties is important to provide new options for customers.

It is predicted that the profit in the future after the development is done will be approximately $\mathrm{Rp}$ $19,500,000$. The details are as follows:

1. The production cost of one tray is $\mathrm{Rp} 13,000$.

2. If the daily target sold is 50 trays, then it will become Rp 650,000.

3. In a month, a net profit can be obtained of Rp 19,500,000.

\section{Mayusi Cloth}

The ever increasing fashion developments have resulted in various innovative works, such as by combining clothing designs which can be used by nursing mothers. Fashionable clothing models will add to nursing mothers' confidence to do their motherly roles. The uniqueness of this product, which is designed with a Sabrina model, a long dress, and jumpsuit, is so that it provides special access for mothers to nurse their babies. Besides that, there is also a bust holder in the clothing design which adds to the practical value of this product. This product's market target is nursing mothers.

The competitor of this product is nursing bras, because nursing mothers still tend to wear bras to nurse their infants rather than nursing clothing. The business location for making this product will be in a strategic location that is advantageous with an empty space where there is a house as the production place. They will choose a home industry location. The financial plan will be divided into four parts, which are the business early capital of $\mathrm{Rp} 12,475,000$, a cash flow statement of $\mathrm{Rp} 81,378,000$, a rate of return analysis of $6.5 \%$, and a BEP analysis of 1,500 pieces for 15 months.

The making of this product starts with a survey of the material, a survey of the seamstresses who can be contracted to make the clothing, as well as a survey of the marketing place. The materials that are needed are rayon fabric, thread, zippers, and bust holders. Then it is continued by making the clothing designs which are then taken to the seamstresses to be sewed. The SWOT analysis of this product consists of the strength of this product, which is it is able to become an innovation by introducing nursing clothing, because nursing mothers still do not know about nursing clothing. In addition, it is practical because the clothing is designed with an additional bust holder. The weakness of this product is that only a few mothers are familiar with nursing clothing, and not enough mothers do nursing exclusively. The 
opportunity of this product is a fashionable and innovative clothing design which is able to attract the attention of nursing mothers. There are no companies which produce clothing with an additional bust holder design, and the price is relatively affordable. The threat of this product is that there is a new competitor which offers a simpler and fashionable design, and there is a new clothing innovation made from quality material as well as more interesting color choices. The business plan in developing this product is seen from the consumer target that strays from nursing mothers. The potentials of this market segmentation are seen in the field from the market condition that still does not produce a sufficient amount of nursing clothing that has fashionable styles. This product is marketed through online media in the form of Facebook social networking, an online buying and selling website, and Instagram. The price for one nursing clothing is $\mathrm{Rp} 160,000$. The competition and opportunities in producing this kind of clothing depends on nursing mothers' higher interest towards nursing bras than nursing clothing. The business sustainability of producing Baju Mayusi will be produced intermittently every month and marketed to the general public with various fashionable and trendy designs.

\section{Technology Based Duck Egg Hatching}

Egg hatching machines are one of the instruments that are often used in fowl breeding. These machines are used to improve the quantity of eggs hatched. Even though there are already many egg hatching machines that are produced manually, semi-automatically, and automatically, the level of success or percentage of egg hatchability is still low. One of the reasons that have a great influence is the uneven temperature distribution. The ideal temperature and humidity needed for eggs during the incubation process is between $360 \mathrm{C}-400 \mathrm{C}$, and the humidity is between $55 \%-65 \%$.

The purpose of this development is to implement a temperature and humidity controller for the duck egg incubation location, in order that it can increase the percentage of hatched eggs. This controller is made, so that the manual hatching becomes automatic. This system will maintain the ideal temperature and humidity according to what is needed. The testing of this development includes calibrating the temperature and humidity, which uses a temperature measurement and a standard humidity measurement with the temperature and humidity that are received by the sensor used. It can be concluded that by using an automatic controller, the percentage of success in egg hatching is better compared with another controller.

While this egg hatching business has been operating, they have experienced several constraints, such as the unstable humidity level in the incubator. Therefore, they hope to design a second incubator and develop a technology method, so that the results will be more maximal.

\subsection{Determinant Factors of Entrepreneurship Education}

Entrepreneurship Education is an important course for higher education institutions to develop students' enthusiasm through their abilities to produce technological innovations as well as change them to become social and economic innovations. Entrepreneurship Education is expected to be able to motivate students to become entrepreneurs when they have finished their studies. Entrepreneurship Education is 
also expected to become a means to instill the values of hard work, diligence, perseverance, the need for achievement, the willingness to try, independence, creativity, and innovation.

To achieve education which can fulfill the expectations as listed above, there are many factors which can influence them, which are the determinants of Entrepreneurship Education. These factors need to be known, in order that when implementing Entrepreneurship Education, efforts can be made to produce quality Entrepreneurship Education. As what was explained in the Literature Review, the components of the determinant factors are educators, students, the curriculum and syllabi, and the education infrastructure. Each of these factors can be explained as detailed below.

In an education and learning context, educators are a vital and significant factor. Educators can function as motivators to build and increase enthusiasm, optimism, hard work, diligence, and resilience. Educators can also function as facilitators where educators play a role to assist students in fostering their entrepreneurial spirit. This facility can be provided by educators themselves or they can open access to other parties. Educators also function by providing examples to provide inspiration to students. Educators also need to have qualifications and competence to carry out their roles as Entrepreneurship Education instructors.

From the research that was done by Undhira, it seems that educators influence the knowledge of Entrepreneurship Education. Thus, educators are a determinant factor. There are several possible reasons for this. First, nowadays educators have started to realize that lecturers must provide examples first. To produce successful Entrepreneurship Education, lecturers should have their own businesses first, so that they can share their experiences to provide inspiration and motivation for their students.

If considering the empirical data, in general, educators have qualifications that relatively support Entrepreneurship Education. They have business experience, so that it makes the students want to start their own businesses and become consultants for them. They have high spirit and motivation to produce new entrepreneurs from their graduates.

Based on this fact, it is important to know that educators who successfully develop Entrepreneurship Education that produces graduates who are entrepreneurs are educators who have already had enterprises or have competence in their fields, have enthusiasm and motivation, and are actively involved as good mentors for their students to produce new entrepreneurs from higher education institutions.

Students are an important group who react because there are actions from educators who respond with improving their knowledge, attitudes, and expertise. The presence of students is very important to have a quality learning process. The characteristics, abilities, desires, and capacities of students will influence their responses in the actions that occur within themselves. The values, perceptions, mindsets, habits, norms, beliefs, and expectations, which are the actualization of their culture, will greatly influence the learning absorption process which occurs. 
When they are asked about what strengths and weaknesses they have, students who are successful in running their businesses usually have strengths like a feeling of self-confidence and readiness to work hard and do not look at their weaknesses.

Based on the research results, it was discovered that in general they enjoy looking for jobs when they graduate. At this time, they cannot yet imagine what it will be like to become an entrepreneur. When they enter a higher education institution, they certainly think about where they want to work. Not too many of them enter a higher education institution to become an entrepreneur. They do not yet understand and convey their intentions actively. Their mindsets, perceptions, habits, norms, beliefs, and expectations do not yet support them in the entrepreneurship teaching and learning process. Those who respond are usually in a hurry or forced to do it because there is no other choice. They usually have financial difficulties, so that they want to overcome it buy running a business. In the entrepreneurship theory, this kind of a condition makes them become an accident entrepreneur, someone who becomes an entrepreneur because it is unplanned and maybe because there is no other option.

\subsection{Entrepreneurship Education and Student Performance}

Entrepreneurship Education is expected by many parties to be able to produce graduates who become capable entrepreneurs. Many theories have mentioned that a quality Entrepreneurship Education program will be able to produce new entrepreneurs.

Based on this fact, the implementation of Entrepreneurship Education is still various. Due to this variation, its components are also various, so that there are numerous components involved in Entrepreneurship Education. In the past, Entrepreneurship Education was only related with sales expertise. However, nowadays the components of Entrepreneurship Education should at least consist of a change of mindset, an increase in motivation, entrepreneurial skills, and business skills.

According to the theory that has been mentioned previously, a quality Entrepreneurship Education program will also produce quality graduate performance. After doing an examination and analysis, it was found that the Entrepreneurship Education variable has a positive and significant influence towards student performance. This shows that the empirical test results support the hypothesis that was proposed previously.

A mindset or way of thinking or way to evaluate something greatly influences entrepreneurial behavior. An individual's mindset will lead that person to what will be done or made. In other words, failure in a business is often caused by having a fixed mindset. Therefore, Entrepreneurship Education must contain how to change a mindset from being a fixed mindset to a growth mindset. This change in mindset will become a basis for other Entrepreneurship Education components (Priyanto, 2012).

In this research, it was revealed that when Entrepreneurship Education changes students' mindsets, it will produce quality graduates. In contrast, if Entrepreneurship Education does not have a change of mindset, usually the program cannot produce quality graduates. 
Many articles have shown the important role of motivation. If an individual does not have motivation, then the person will not have high performance. Motivation will drive various aspects which are related with effort and its ability to run, control, and reach goals. In his theory, David McClelland stated that an entrepreneur becomes successful if he/she has strong and high motivation. A person who has a high need for achievement, a high entrepreneurial spirit, and good work performance will be better than someone who has a low need for achievement (McClelland, 1961, 1965, 1987).

In this research, it was found that motivation is related with student performance. Motivation has a positive influence towards student performance. Students who have strong motivation to get ahead and strive will have good business performance. As mentioned previously, an individual's personal values like strong motivation to advance, skills, and abilities greatly affect the individual in one's decision making process, so that the person can make the right decision. Personality, intelligence, and motivation are important factors in molding individual behavior which will influence someone in responding to any environmental changes that may occur, including producing high performance. This means that these research results support the previous finding that motivation influences someone's performance.

An entrepreneurial skill is the expertise owned by someone who is able to utilize one's inner creative desires in business. This need consists of being brave to try something, independent, creative, innovative, able to construct one's business inspirations, and ultimately able to assemble the resources owned and the resources in the environment.

These research results demonstrate that business skills are strongly connected with student performance. Besides that, business skills have a positive influence towards student performance. This means that if someone's business skills are high, then the business performance will also be high.

If students are asked about what they want to be in the future, the majority of them will answer they want to become entrepreneurs. If they are asked what obstacles they face in running their businesses, they will certainly answer financial capital. Is that really the situation? The ethnomethodological research that was done by the author along with teaching Entrepreneurship Education at a campus, seems to have several things which must be given attention and prepared for students who want to become entrepreneurs.

In borrowing the ideas of Shane, Locke, and Collins (2003), the first aspect which needs to be done is entrepreneurial motivation which consists of a need for achievement, risk taking, innovative, a desire for independence, goal setting, and self-efficacy. To be successful in running a start-up, students need to have these characteristics. The second aspect is regarding the cognition factor, which is in the form of knowledge and its importance in making a life vision to influence someone's entrepreneurship. Students who understand the importance and role of a vision will strive to make and record their life visions. When they make their life visions, an unconscious desire will surface that they can reach these visions. Knowledge becomes an important source for entrepreneurship. Students who know something will be better able to put together a structure, system, and new ideas than students who do not have much knowledge. Students who are full of knowledge will easily look for a path when they experience difficulties. Or they will be able to see opportunities or have new ideas through the knowledge that they 
possess. Students who have expertise will also be able to create ideas and innovations by basing them on the skills they own. With the skills that they possess, they will be better able to create something to add, perfect, or even replace ideas. Students who have expertise in making a web-based application will find it is easier to adjust themselves if there are changes in technology and the business environment compared with students who are not experts. This signifies that it is important for us to be experts in the fields we work in, so that it facilitates us to be more creative and innovative than before.

When students have entrepreneurial motivation and have followed and been educated to become entrepreneurs cognitively, it is not enough for them to become entrepreneurs instantly. To improve that acceleration, they have to be given or receive entrepreneurship opportunities from their campus or environment. Related to this, Entrepreneurship Education at campus should not only focus on structured teaching in the classroom with its cognition aspect, but it also needs to be enriched by giving them the opportunity to try for themselves to make a start-up, so that in this stage, there will be a connection between cognitive knowledge and behavioral knowledge. Learning about entrepreneurship is actually effective when they feel directly what it is like to become an entrepreneur. To achieve this, the Entrepreneurship course at President University applies an entrepreneurial learning model with three main learning foundations, which are training and education, experience, and mentoring.

The next aspect which needs to be given to students who will begin a start-up is their ability to see an opportunity. People's mental abilities are all different. In the same environment, it is not certain that they will be able to capture the same things. As a result, in the Entrepreneurship course, students need to repeatedly be given material in the form of business concepts that are proper to be implemented, so that in the end students will obtain a pattern about how to recognize opportunities.

People who recognize opportunities will not necessarily have business ideas. To possess an entrepreneurship ability like this, students or society need to be trained or guided about particular ideas which can become businesses. This ends in the economic business feasibility like profit, turnover, market, and sustainability.

After that, what needs to be given to students or society, in order that they can become entrepreneurs is to assemble resources. An online batik business idea or a fintech application business idea must be continued with expertise about how to recognize a market, who wants to buy, how to get them to buy our goods and services, how to understand where funds come from, how big they are, what will it cost to get it, how many years if a loan is taken out, and how to develop the funding. After everything is ready, the product design needs to be made, starting from the volume, kind, and characteristics of the good or service. The location aspect, whether it is online or offline, also needs to be understood and carried out to obtain it.

When all of this is given to students or society, in the end, what determines whether a start-up is successful or not is the student or citizen oneself. In principle, becoming an entrepreneur is an ongoing learning process. Whoever wants to learn from a business that is being run and actualize it, this is the person who will become an entrepreneur. Becoming an entrepreneur is an internal and individual process, 
which is very subjective. Based on this kind of subjective reality, an entrepreneur can only be born into this world.

\section{Conclusion}

The dynamic of implementing the entrepreneurial learning model (ELM) at higher education by emphasizing three aspects: training and education, experience, and mentoring, as well as applying the Shane Theory in recognizing ideas, developing ideas, and assembling resources, shows that students' entrepreneurial performance is greatly related with students, educators, and the learning methods applied. Through action research, starting from the program socialization stage, entrepreneurship seminars, and ending with an entrepreneurship potential test, business idea selection, proposal selection, grant provisions, business implementation, mentoring by entrepreneurs, internships, gatherings, monev, business exhibitions, as well as in entrepreneur communities, shows that students who have quality business visions, have a strong motivation for success, are hard workers, have a background with parents as entrepreneurs, have a high intensity to do a start-up, and are in an appropriate field with their subject disciplines, will be more successful than those who are different. Also, businesses which match with one's hobbies also have the prospect to become a start-up. Leadership ability, entrepreneurial capability, managerial skill, personality, as well as the ability to assemble resources are determinant factors in the success of a start-up.

This research used Shane's idea framework in developing an enterprise. However, this research has not subjectively and individually gone in-depth into how the entrepreneurship process in a start-up can recognize opportunities to create ideas, start a business, and develop a business. It has not gone in-depth to explain the influence of the program towards developing students' entrepreneurial competence and spirit, especially in how it affects their academic ability. Consequently, future research needs to be conducted in this scope.

The construction of the blended entrepreneurial learning framework still needs to be refined in its concept and implementation related with the effectiveness in its application. Therefore, future research can be directed to this aspect. Dickfos, Cameron, and Hodgson (2014) stated that a blended learning approach that integrates theory and practice through a simulation aligns well with the needs of learners undertaking professional development. It is different from blended entrepreneurial learning that we have been proposed. this can be the next study to look for differences and the meeting point of these two things.

\section{Declarations}

\section{Availability of data and materials}

The datasets used and/or analysed during the current study are available from the corresponding author on reasonable request 


\section{Competing interests}

The authors declare that they have no competing interests

\section{Funding}

This research including the design of the study and collection, analysis, and interpretation of data and in writing the manuscript funded by Ministry of Research, Technology and Higher Education of Indonesia, who provided fund for our research project 2019-2020.

\section{Authors' contributions}

Each author have made substantial contributions to the conception, design of the work; the acquisition, analysis, interpretation of data; the creation of new software used in the work; have drafted the work or substantively revised it

\section{Acknowledgments}

The authors are grateful to Ministry of Research, Technology and Higher Education of Indonesia, who provided fund for our research project 2019-2020.

\section{Authors'information}

1. Tri Priyono Budi Santoso. Lecturer in Managemen, Universitas Dhyana Pura, Jalan Raya Padang Luwih Tegaljaya Dalung Kuta Utara - Bali -80361 Indonesia. Email: budisantoso@undhirabali.ac.id

2. I Wayan Ruspendi Junaedi, Lecturer in Managemen, Universitas Dhyana Pura, Jalan Raya Padang Luwih Tegaljaya Dalung Kuta Utara - Bali -80361 Indonesia. Email: ruspendijunaedi@undhirabali.ac.id

3. Sony Heru Priyanto, Lecturer in Entrepreneurship Program, Universitas Podomoro. Central Park Mall Lt 3 - Unit 112, Podomoro City, Jl. Let Jend S. Parman Kav 28, Jakarta Barat 11470, Indonesia. Email: sonecid@yahoo.com

4. Donald Samuel Slamet Santoso, Sosial Humaniora Lecturer, President University, Ki Hajar Dewantara, Kota Jababeka, Cikarang Baru, Bekasi 17550 - Indonesia. Email: dsamuel@president.ac.id

\section{References}

Ács, Z. J., \& Naudé, W. (2013). Entrepreneurship, stages of development, and industrialization. Pathways to Industrialization in the 21st Century, 373-392.

Baum, J. R., Locke, E. A., \& Smith, K. G. (2001). A multidimensional model of venture growth. Academy of management journal, 44(2), 292-303. 
Baumol, W. J. (1993). Formal entrepreneurship theory in economics: Existence and bounds. Journal of business venturing, 8(3), 197-210.

Baumol, W. J. (2003). On Austrian analysis of entrepreneurship and my own Austrian economics and entrepreneurial studies (pp. 57-66): Emerald Group Publishing Limited.

Blaise, C. (2011). Time lord: Sir Sandford Fleming and the creation of standard time: Vintage.

Bolton, D. L., \& Lane, M. D. (2012). Individual entrepreneurial orientation: Development of a measurement instrument. Education+ Training, 54(2-3), 219-233.

Bolton, P., Brunnermeier, M. K., \& Veldkamp, L. (2010). Economists' perspectives on leadership. Handbook of leadership theory and practice, 239-264.

Chase, S. E. (2005). Narrative inquiry: Multiple lenses, approaches, voices.

De Fina, A., \& Georgakopoulou, A. (2019). The handbook of narrative analysis: Wiley-Blackwell.

Dickfos, J., Cameron, C., \& Hodgson, C. (2014). Blended learning: making an impact on assessment and self-reflection in accounting education. Education+ Training, 56(2/3), 190-207.

Floyd, A. (2012). Narrative and life history. Research methods in educational leadership and management, 230-241.

Gartner, W. B., Carter, N. M., \& Reynolds, P. D. (2010). Entrepreneurial behavior: Firm organizing processes Handbook of entrepreneurship research (pp. 99-127): Springer.

Hood, J. N., \& Young, J. E. (1993). Entrepreneurship's requisite areas of development: A survey of top executives in successful entrepreneurial firms. Journal of business venturing, 8(2), 115-135.

Hull, G. S. (2010). Immigrant Entrepreneurs: The face of the new nashville. I-Business, 2(1), 1.

lakovleva, T., Kolvereid, L., \& Stephan, U. (2011). Entrepreneurial intentions in developing and developed countries. Education+ Training, 53(5), 353-370.

Johannisson, B. (2018). Limits to and prospects of entrepreneurship education in the academic context $A$ Research Agenda for Entrepreneurship Education: Edward Elgar Publishing.

Kirzner, I. M. (1999). Creativity and/or alertness: A reconsideration of the Schumpeterian entrepreneur. The Review of Austrian Economics, 11(1), 5-17.

Kirzner, I. M. (2015). Competition and entrepreneurship: University of Chicago press.

Kourilsky, M. L. (1995). Entrepreneurship Education: Opportunity in Search of Curriculum. 
Kristof-Brown, A. L., Zimmerman, R. D., \& Johnson, E. C. (2005). CONSEQUENCES OF INDIVIDUALS'FIT AT WORK: A META-ANALYSIS OF PERSON-JOB, PERSON-ORGANIZATION, PERSON-GROUP, AND PERSON-SUPERVISOR FIT. Personnel psychology, 58(2), 281-342.

Lee, D. Y., \& Tsang, E. W. (2001). The effects of entrepreneurial personality, background and network activities on venture growth. Journal of Management studies, 38(4), 583-602.

Link, A. N., \& Scott, J. T. (2012). Employment growth from the small business innovation research program. Small Business Economics, 39(2), 265-287.

McClelland, D. C. (1961). Entrepreneurial behaviour and Characteristics of entrepreneurs. The Achieving Society.

McClelland, D. C. (1965). N achievement and entrepreneurship: A longitudinal study. Journal of personality and Social Psychology, 1(4), 389.

McClelland, D. C. (1987). Characteristics of successful entrepreneurs. The journal of creative behavior, 21(3), 219-233.

Noyes, E., \& Deligiannidis, L. (2013). Grasping change: visualizing international technology adoption for entrepreneurship education. Journal of Entrepreneurship Education, 16, 13.

Pretorius, M., Nieman, G., \& Van Vuuren, J. (2005). Critical evaluation of two models for entrepreneurial education: An improved model through integration. International Journal of Educational Management, 19(5), 413-427.

Priyanto, S. H. (2012). Entrepreneurial and vocational learning in entrepreneurship education: Indonesian non formal education perspective. Basic research journal of business management and accounts, 1(2), 30-36.

Priyanto, S. H., \& Sandjojo, I. (2005). Relationship between entrepreneurial learning, entrepreneurial competencies and venture success: empirical study on SMEs. International Journal of Entrepreneurship and Innovation Management, 5(5-6), 454-468.

Reicher, S. D., Haslam, S. A., \& Platow, M. J. (2018). Shared social identity in leadership. Current opinion in psychology, 23, 129-133.

Schumpeter, J. A. (1934). The theory of economic development: An inquiry into profits, capital, credit, interest, and the business cycle (Vol. 55): Transaction publishers.

Shane, S., Locke, E. A., \& Collins, C. J. (2003). Entrepreneurial motivation. Human resource management review, 13(2), 257-279.

Siedel, G. J. (2014). Negotiating for Success: Essential Strategies and Skills: Van Rye Publishing, LLC. 
Stevenson, H., \& Jarillo. (1990). et JC Jarillo, 1990. A Paradigm of Entrepreneurship: Entrepreneurial.

Szirmai, A., Naudé, W., \& Goedhuys, M. (2011). Entrepreneurship, innovation, and economic development. Oxford University Press.

Thom, M. (2017). The Difficulty Of Practising Fine Artists In Making A Living: Why Arts Entrepreneurship Education Is Important. London South Bank University.

Van Vuuren, J., \& Nieman, G. (1999). Entrepreneurship education and training: A model for syllabi/curriculum development. Paper presented at the 44th ICSB World Conference Proceedings.

Weaver, M., Dickson, P., \& Solomon, G. (2006). Entrepreneurship and education: what is known and not known about the links between education and entrepreneurial activity. The small business economy: $A$ report to the president, 113-156.

Welsch, P. H. (1993). Entrepreneurship education and training infrastructure: External interventions in the classroom. Paper presented at the 4th Internationalisation Entrepreneurship Conference, Vienna. 